\title{
Analisis faktor yang mempengaruhi penerimaan pendapatan asli daerah Kabupaten Muaro Jambi
}

\author{
Abunyani*; Parmadi; Erfit \\ Prodi Ekonomi Pembangunan Fak. Ekonomi dan Bisnis Universitas Jambi \\ *E-mail korespondensi:abunyani111@gmail.com
}

\begin{abstract}
This study, entitled factor analysis affecting the revenue of original region of Muaro Jambi Regency. The purpose of this study is to analyze the effect of gross domestic product per province and the number of residents on the local revenue in Muaro Jambi District during 2005-2015. The methods of analysis are used in this study qualitative descriptive analysis and quantitative analysis by using an analysis tool, like a multiple regression analysis models. The results of this study based on the calculation of statistical test show hypothesis test using $t$ statistic show partially significant variable is GDP per province has a positive effect on revenue of locally-generated revenue (PAD) in Muaro Jambi regency, while population growth has no positive effect on the locally-generated revenue (PAD) in Muaro Jambi regency. Based on the statistical $f$ test shows all the coefficients of multiple linear regression or variable (Overall) of regression coefficients consisting of GDP per province and Population positively affect the revenue of locally-generated revenue (PAD) in Muaro Jambi regency.
\end{abstract}

Keywords: Locally-generated revenue, Gross regional domestic product, Total population

\begin{abstract}
Abstrak
Penelitian ini berjudul analisis faktor yang mempengaruhi penerimaan pendapatan asli daerah Kabupaten Muaro Jambi. Tujuan dalam penelitian ini untuk menganalisis Pengaruh produk domestik regional bruto dan jumlah penduduk terhadap pendapatan asli daerah di Kabupaten Muaro Jambi Selama Periode Tahun 2005-2015. Metode analisis yang digunakan dalam penelitian ini analisis deskriptif kualitatif dan analisis kuantitatif menggunakan alat analisis yaitu regresi linier berganda. Adapun hasil penelitian ini berdasarkan perhitungan uji statistik yaitu uji hipotesis menggunakan t statistik secara parsial menunjukan variabel berpengaruh signifikan adalah PDRB berpengaruh yang positif terhadap penerimaan PAD di Kabupaten Muaro Jambi, sedangkan pertumbuhan penduduk tidak berpengaruh yang terhadap penerimaan PAD di Kabupaten Muaro Jambi. Berdasarkan uji F statistik menunjukan bahwa secara silmultan (bersama-sama) bahwa semua koefisien regresi linier berganda atau variabel secara bersama- sama (Overall) koefisien regresi yang terdiri dari PDRB dan Penduduk berpengaruh secara positif terhadap penerimaan PAD di Kabupaten Muaro Jambi.
\end{abstract}

Kata kunci :Pendapatan asli daerah, Produk domestik regional bruto, Jumlah penduduk 


\section{PENDAHULUAN}

Semakin banyak kebutuhan yang dapat di biayai oleh PAD maka semakin tinggi tingkat kualitas otonomi daerah, sehingga dapat di katakan mandiri dalam bidang keuangan daerah dan semakin mengurangi tingkat ketergantungan terhadap pemerintah pusat. Adapun proporsi PAD Kabupaten Muaro Jambi pada tahun 2015 masih 4,68 persen dari total pendapatan daerah, lebih kecil di banding dengan rata-rata nasional sudah mencapai 6,63 persen dari total anggaran pendapatan Negara (BPS, 2016).

Menurut data Badan Pusat Statistik tahun 2015 Pada lima tahun terakhir penerimaan daerah selalu mengalami peningkatan dari tahun 2011 - 2015 yaitu pada tahun 2011 penerimaan daerah sebesar Rp. 715.200.674 dan meningkat pada tahun 2012 sebesar Rp. 844.685.086 atau sebesar 18,10 persen, pada tahun 2013 meningkat kembali sebesar Rp. 957.224.573 atau sebesar 13,32 persen, pada tahun 2014 juga meningkat sebesar Rp. 992.195.529 atau sebesar 3,65 persen dan pada tahun 2015 mengalami peningkatan sebesar Rp. 1.179.105.854 atau sebesar 18.83 persen dengan adanya peningkatan terus menerus terhadap penerimaan daerah di Kabupaten Muaro Jambi yang bersumber dari PAD, dana perimbangan dan lain-lain pendapatan yang sah.

PAD di Kabupaten Muaro Jambi mengalami peningkatan selama periode tahun 2011 - 2015 jika pada tahun 2011 PAD sebesar Rp. 28.413.651 maka meningkat pada tahun 2012 menjadi Rp. 36.510 .508 atau sebesar 28,50 persen. Pada tahun 2013 meningkat kembali menjadi Rp. 48.531 .323 atau naik sebesar 32,92 persen, pada tahun 2014 juga menjadi sebesar Rp. 61.448.570 atau naik sebesar 26,62 persen dan pada tahun 2015 mengalami peningkatan sebesar Rp. 69.125.897 atau naik sebesar 12.49 persen. Peningkatan PAD Kabupaten Muaro Jambi setiap tahunnya berorientasi pada peningkatkan pembangunan daerah. Adapun permasalahan yang harus diatasi anatar lain adalah bagaimana kontribusi PAD dalam meningkatkan perekonomian, mengingat pentingnya peran PAD dalam pembangunan daerah.

Perkonomian dari suatu wilayah dan kinerjanya dapat diamati melalui beberapa indikator makro. Indikator makro tersebut dapat dianalisis melalui Produk Domestik Regional Bruto (PDRB) yang dapat didefinisikan sebagai penjumlahan nilai tambah bruto yang dihasilkan oleh seluruh unit kegiatan ekonomi yang beroperasi di wilayah/daerah tersebut dalam periode tertentu. Jadi PDRB adalah nilai tambah yang pengukurannya berdasarkan adanya aktivitas ekonomi di suatu wilayah. Pertumbuhan ekonomi daerah berkaitan erat dengan peningkatan produksi barang dan jasa, yang diukur dengan besaran dalam PDRB, dan juga sebagai indikator untuk mengetahui kondisi ekonomi suatu daerah dalam suatu periode tertentu.

PDRB di Kabupaten Muaro Jambi mengalami peningkatan dari tahun 2011 - 2015 yaitu pada tahun 2011 PDRB sebesar Rp. 10.134.022 dan meningkat pada tahun 2012 sebesar Rp. 10.866.516 atau sebesar 7.23 persen, pada tahun 2013 meningkat kembali sebesar Rp. 11.643 .599 atau sebesar 7.15 persen, pada tahun 2014 juga meningkat sebesar Rp. 12.578.034 atau sebesar 8.03 persen dan pada tahun 2015 mengalami peningkatan sebesar Rp. 13.447.124 atau sebesar 6.90 persen, semakin tingginya pertumbuhan ekonomi di Kabupaten Muaro Jambi maka akan meningkatkan kemampuan daerah mengelola sumberdaya pembangunan yang dimilikinya, oleh karena itu besaran PDRB setiap daerah bervariasi sesuai dengan potensi yang dimiliki dan faktor produksi masing-masing daerah.

Peningkatan pada masing-masing sector unggulan membawa dampak yang positif bagi perekonomian daerah terutama memberikan kontribusi besar terhadap PAD. Besar kecilnya PAD sangat dipengaruhi oleh tinggi rendahnya pertumbuhan ekonomi daerah secara tegas tercermin di dalam PDRB dan dampak positif dari kebijakan proyek-proyek 
yang didanai atas prioritas dari pemerintah pusat yang selama ini diterima pemerintah daerah dan merupakan sumber pembiayaan terbesar bagi pemerintah daerah. Adapun yang menjadi permaslalahan dalam penelitian ini adalah bagaimana pengaruh PDRB dan jumlah penduduk terhadap PAD di Kabupaten Muaro Jambi selama periode tahun 2005-2015.

\section{METODE}

Untuk menyelesaikan permasalahan keempat terkait dengan pengaruh PDRB dan jumlah penduduk terhadap PAD di gunakan perumusan regresi linier berganda sebagaimana diungkapkan oleh (Gujarati, 2010):

$$
\mathrm{Y}=\mathrm{a}+\boldsymbol{\beta}_{1} X 1+\beta_{2} X 2+\mathrm{e}
$$

Adapun untuk kebutuhan penelitian rumus di sederhanakan menjadi

$$
\text { PAD }=\beta_{0}+\beta_{1} P D R B+\beta_{2} P E N D U D U K+e
$$

Dimana :

$$
\begin{array}{ll}
\text { PAD } & =\text { Pendapatan asli daerah } \\
\mathrm{X} 1 & =\text { PDRB } \\
\mathrm{X} 2 & =\text { Jumlah penduduk }
\end{array}
$$

\section{Uji statistik}

\section{Uji t (t-test)}

Uji t dilakukan untuk menguji signifikan yang ditaksir sebagai pengaruh antara variabel bebas terhadap variabel terikat digunakan uji-t statistik ( $\mathrm{t}$-test) dengan rumus sebagai berikut :

$$
\text { thitung }=\frac{\beta 1}{\operatorname{Se}(\beta 1)}
$$

Dengan membandingkan t-hitung dan t-tabel pada tingkat keyakinan tertentu dapat diambil kesimpulan dengan kriteria sebagai berikut : Jika t-hitung > t-tabel, maka Ho ditolak yang berarti variabel bebas memiliki pengaruh yang signifikan terhadap variabel terikat. Sedangkan Jika t-hitung < t-tabel, maka Ho diterima yang berarti variabel bebas tidak memiliki pengaruh yang signifikan terhadap variabel terikat.

\section{Uji F (F-test)}

Uji F digunakan untuk menguji signifikan koefisien regresi secara bersama. Uji F menunjukkan signifikan pengaruh variabel-variabel bebas secara bersama-sama terhadap variabel terikat. Nilai F-hitung dapat dicari dengan rumus sebagai berikut :

$F$ hitung $=\frac{R^{2} /(k-1)}{\left(1-R^{2}\right) /(n-k)}$

\section{Koefisien determinasi $\left(\mathbf{R}^{2}\right)$}

Analisis ini digunakan untuk mengetahui besaran pengaruh variabel bebas $\left(\mathrm{X}_{1},\right)$ yang diterangkan oleh variabel terikat $(\mathrm{Y})$ dapat dilihat dari nilai $\mathrm{R}^{2}$ (Koefisien Determinan) dengan formulasi :

$$
R^{2}=\beta_{1}^{2}-\left(\begin{array}{ll}
\sum & x_{i}^{2} \\
\hline \sum & y_{i}^{2}
\end{array}\right)
$$


Dimana $\mathrm{r}^{2}$ berkisar antara 0 (nol) sampai 1 (satu), jika mendekati nilai 0 (nol) ini berarti kurang kuat hubungan antara variabel dependen dengan variabel independen. Jika nilainya mendekati 1 (satu) maka ini menunjukkan semakin besarnya hubungan antara kedua variabel tersebut.

\section{HASIL DAN PEMBAHASAN}

Analisis ini dilakukan untuk mengetahui seberapa besar pengaruh PDRB dan jumlah Penduduk terhadap PAD di Kabupaten Muaro Jambi, menggunakan analisis regresi linier berganda, adapun data yang diubah menjadi. maka di peroleh hasil sebagai mana terlihat pada tabel 1.

Tabel 1 Persamaan model regresi linier berganda

\begin{tabular}{ccccc}
\hline Variable & Coefficient & Std. Error & t-Statistic & Prob. \\
\hline C & -23.216602 & 21760522 & -1.066914 & 0.3070 \\
PDRB & 2.336140 & 0.843860 & 2.768398 & 0.0170 \\
Penduduk & 115.6039 & 76.81957 & 1.504875 & 0.1582 \\
\hline R-squared & 0.889081 & Mean dependent var & 25097327 \\
Adjusted R-squared & 0.870595 & S.D. dependent var & 19708778 \\
S.E. of regression & 7089830. & Akaike info criterion & 34.56308 \\
Sum squared resid & $6.03 E+14$ & Schwarz criterion & 34.70469 \\
Log likelihood & -256.2231 & Hannan-Quinn criter. & 34.56157 \\
F-statistic & 48.09359 & Durbin-Watson stat & 0.740910 \\
Prob(F-statistic) & 0.000002 & & \\
Sumber : Data diolah, 2018 & &
\end{tabular}

Berdasarkan Tabel 1 dari hasil estimasi di atas dapat dituliskan persamaaan sebagai berikut:

\section{PAD $=$-23.216602 + 2.336140 PDRB + 115.6039 Penduduk}

Interprestasi hasil dijelaskan sebagai berikut:

Nilai kostanta pada penelitian sebesar 23.216602, artinya jika variable PDRB dan penduduk nilai koefisiennya sama dengan nol atau tidak berubah maka penerimaan PAD akan menurun sebesar Rp.23.216.602. Pada variabel PDRB diketahui koefisien regresinya sebesar 2.336140, koefisien ini mempunyai arti jika PDRB meningkat satu juta maka akan menyebabkan penerimaan PAD di Kabupaten Muaro Jambi meningkat sebesar Rp.2.336.140 apabila variabel lain dianggap tetap. Pada variabel penduduk diketahui koefisien regresinya sebesar 115.6039, koefisien ini mempunyai arti jika penduduk bertambah satu jiwa maka akan menyebabkan penerimaan PAD di Kabupaten Muaro Jambi meningkat sebesar Rp.115.6039 apabila variabel lain dianggap tetap.

\section{Uji koefisien determinasi ( $\mathbf{R}^{2}$ )}

Uji ini digunakan untuk mengetahui berapa persen variasi variabel dependen yang bisa dijelaskan variabel independen. Dari hasil regresi diketahui bahwa nilai $\mathrm{R}^{2}$ adalah 0.889081 sehingga dapat katakan bahwa 88.90 persen penerimaan PAD di Kabupaten Muaro Jambi dijelaskan oleh variabel PDRB dan penduduk. Sedangkan sisanya 11.10 persen di jelaskan faktor lain diluar penelitian. 


\section{Uji hipotesis}

\section{Uji F statistik}

Dengan demikian $\mathrm{F}$ tabel dengan tingkat signifikansi 0.05 persen adalah $11=$ 3,84 karena F hitung (48.09359) > F tabel ( 3,84 ) maka ho ditolak atau berbeda dengan nol. Artinya bahwa semua koefisien regresi atau semua variabel PDRB dan penduduk secara bersama - sama berpengaruh terhadap penerimaan PAD di Kabupaten Muaro Jambi.

\section{Uji t ( Uji parsial )} berikut:

Berdasarkan hasil persamaan regresi di dapat hasil uji parsial setiap variabel sebagai

Tabel 2. Hasil uji t pada tingkat signifikansi 0.05

\begin{tabular}{cccc}
\hline Variabel & t.hitung & t.tabel & Kesimpulan \\
\hline PDRB & 2.768398 & 1.77 & Berpengaruh \\
Penduduk & 1.504875 & 1.77 & Tidak berpengaruh \\
\hline
\end{tabular}

Sumber : Data diolah

Berdasarkan Tabel 2 menunjukan secara rinci, uji t terhadap persamaan tersebut hitung sebesar 2.768398 diperoleh $\mathrm{t}$ hitung $>\mathrm{t}$ tabel 1.77 maka ho ditolak dan ha diterima, artinya bahwa pada tingkat signifikansi 0.05 persen variabel PDRB mempunyai pengaruh signifikan terhadap penerimaan PAD di Kabupaten Muaro Jambi. thitung sebesar 1.504875 $<\mathrm{t}$ tabel 1.77 maka ho diterima dan ha ditolak, artinya bahwa pada tingkat signifikansi 0.05 persen variabel Penduduk tidak signifikan terhadap penerimaan PAD di Kabupaten Muaro Jambi.

\section{KESIMPULAN DAN SARAN}

\section{Kesimpulan}

Adapun berdasarkan perkembangan PAD dalam kurun waktu 2005 - 2015 perkembangan tertinggi terjadi pada tahun 2011 dan perkembangan terendahnya pada tahun 2008. Struktur perekonomian yang tertinggi banyak terdapat pada sector pertanian dan pertambangan sedangkan pada sector listrik, keuangan dan jasa - jasa pertumbuhan cukup rendah tetapi mengalami peningkatan setiap tahunnya. Adapun berdasarkan perkembangan Jumlah Penduduk dalam kurun waktu 2005 - 2015 Pertumbuhan penduduk yang paling tinggi terjadi pada tahun 2010 dan pertumbuhan penduduk yang rendah terdapat pada tahun 2006. Berdasarkan hasil pengujian statistik menggunakan perhitungan regresi linier berganda bahwa jika diuji hipotesis dengan uji F statistic yaitu uji secara sama-sama bahwa semua variabel PDRB dan Penduduk secara bersama - sama berpengaruh terhadap PAD di Kabupaten Muaro Jambi sedangkan di uji melalui uji t statistik bahwa variabel PDRB mempunyai pengaruh signifikan terhadap PAD di Kabupaten Muaro Jambi dan Penduduk tidak mempunyai signifikan terhadap PAD di Kabupaten Muaro Jambi.

\section{Saran}

Untuk mengoptimalisasi sumber-sumber penerimaan daerah perlu dilakukan intensifikasi dan ekstensifikasi subjek dan objek pajak. Dalam jangka pendek kegiatan yang paling mudah dan dapat segera dilakukan adalah melakukan intensifikasi terhadap objek atau 
sumber pendapatan daerah yang sudah ada melalu pemanfaatan teknologi. Untuk meningkatan penerimaan daerah Kabupaten Muaro Jambi pemerintah perlu menggali objek pungutan baru yang potensial dengan lebih memprioritaskan kepada Pendapatan asli daerah, retribusi daerah, pajak daerah, hasil perusahaan milik negara dan pendapatan lain - lain PAD yang sah, daerah untuk ditetapkan dan dijabarkan dalam peraturan daerah. Sebaiknya Pemerintah Kabupaten Muaro Jambi dapat mempertahankan dan meningkatkan sumber sumber pendapatan asli daerah tersebut dalam rangka untuk meningkatkan kemampuan Kabupaten Muaro Jambi dalam mendorong pertumbuhan ekonomi, maka secara perlahan harus mengurangi ketergantungan akan dana perimbangan dari pemerintah pusat serta menjadikan PAD sebagai sumber penggerak pertumbuhan ekonomi. Masyarakat harus selalu mendukung kebijakan yang dibuat oleh pemerintah daerah yang bersifat membangun. Oleh karena itu sumber daya dimiliki pemerintah Kabupaten Muaro Jambi harus benar- benar dikembangkan secara optimal agar tujuan penerimaan daerah dapat tercapai sesuai target. Dalam meningkatkan pendapatan asli daerah Kabupaten Muaro Jambi diperlukannya peran pemerintah dalam mengatur penerimaan daerah dengan meningkatkan kinerja keuangan dengan mencari sumber - sumber penerimaan yang baru yang termasuk di dalam pendapatan asli daerah di Kabupaten Muaro Jambi.

\section{DAFTAR PUSTAKA}

Arsyad.(2010).Pengantar perencanaan dan pembangunan ekonomi daerah. BPFE: Yogyakarta

Bastian.(2001).Akuntansi sektor publik. BPFE, Universitas Gajah Mada: Yogyakarta. Basuki.(2007). Pengelolaan keuangan daerah. Kreasi wacana: Yogyakarta BPS.(2005-2015).Kabupaten Muaro Jambi: Jambi BPS. 2016, Kabupaten Muaro Jambi. Jambi

Devita,Andri.,Arman,Delis \& Junaidi.(2014).Pengaruh pendapatan asli daerah, dana alokasi umum dan jumlah penduduk terhadap belanja daerah kabupaten/kota di Provinsi Jambi. Jurnal Perspektif Pembiayaan dan Pembangunan Daerah. 2(2), 63-70

Dinsosnakertrans.(2009).Tentang struktur ketenagakerjaan Kabupaten Muaro Jambi: Jambi Djaenuri.(2012). Hubungan keuangan pusat dan daerah. Ghalia Indonesia: Jakarta

Dominanto.(2007).Analisis pendapatan daerah Kabupaten Muaro Jambi. Universitas: Jambi

Gujarati., Damodar N. Dawn C \&Porter.(2010). Basic econometrica. fifth edition. Mc Graw Hill: New York

H Basri, Syaparuddin, Junaidi.(2013). Pemetaan kinerja pendapatan asli daerah dan kemampuan keuangan daerah Kabupaten/Kota di Provinsi Jambi, Jurnal Perspektif Pembiayaan dan Pembangunan Daerah 1 (2), 81-90

Mardiasmo.(2004).Otonomi dan manajemen keuangan daerah. Andi: Yogyakarta Mulyadi.(2003). Ekonomi sumber daya manusia: dalam persepektif pembangunan. P.T. Raja Grafindo Persada:Jakara.

Suandi.(2006). Analisis konstribusi pajak terhadap pendapatan asli daerah Kabupaten Batanghari periode 1992-2004. Skripsi Universitas Jambi: Jambi

Undang - Undang No. 25 tahun 2005.Tentang perimbangan keuangan antara pusat dan daerah.

Undang - Undang No. 33 tahun 2004. Tentang pemerintah daerah.

Undang-Undang Nomor 32 Tahun 2004 sebagaimana telah diamandemen dengan UndangUndang-Undang Nomor 12 Tahun 2004 tentang pemerintahan daerah 